\title{
Use of BCG as an immunostimulant in the surgical treatment of carcinoma of the lung
}

\author{
F. RONALD EDWARDS and FRANCIS WHITWELL \\ Cardio-Thoracic Surgical Unit, Broadgreen Hospital, Liverpool L14 3LB
}

\begin{abstract}
Edwards, F. R. and Whitwell, F. (1974). Thorax, 29, 654-658. Use of BCG as an immunostimulant in the surgical treatment of carcinoma of the lung. Cell-mediated immunity to cancer cells would appear to exert some control over the extension of tumour growth, and stimulation of this factor might result in increased survival after surgical treatment of the tumour. Of the various agents used as stimulators in experimental work, BCG would seem to be the most convenient to use in man. A single dose of BCG-Glaxo (500,000 organisms) was given subdermally 10 days after excision of lung carcinoma. The length of survival was used as the index of the effect of the BCG.

Two trials were initiated, the first to study the safety of BCG and a survival study of 120 consecutive cases (60 used as controls). This is an interim report at two years of this trial. The main features at this stage show that the overall survival rate has increased from $38 \%$ in the controls to $52 \%$ in the BCG group. In the squamous-cell group survival has risen from $50 \%$ to $62 \%$ and, in those with positive nodes, from $33 \%$ to $53 \%$. In the oat-cell group, two-year survival has risen from $11 \%$ in the controls to $50 \%$ in the BCG groups, though the numbers are small. Although encouraging, the results are not statistically significant.

The second trial is a randomized trial in which five surgeons have taken part, and 500 consecutive cases of lung resection for carcinoma are documented (250 control and 250 BCG). It is too early for results to be assessed in this group.

It is hoped that at three, four, and five years more favourable survival figures will be obtained.
\end{abstract}

During the process of normal tissue regeneration and repair a very large number of cells in the body (estimated at $10^{11}$ ) are undergoing mitotic changes at any one time. It is reasonable to suppose that on occasions bizarre mitosis may occur and that these abnormal cells are destroyed by inherent processes in the body. Recent immunological studies would indicate that this is one of the roles of the lymphocytes and macrophages (Southam, 1965; Green, Anthony, Baldwin, and Westrop, 1967). There is little evidence as yet in man that a specific immunity develops to abnormal cells, and the steady progress of nearly all malignant neoplasms would suggest that this factor, if present, is a very weak one. Nevertheless, in the experience of all clinicians, the spontaneous regression of a tumour or the long survival of an advanced malignancy, either with or without treatment, has been the occasion for surprise and comment (Gordon-Taylor, 1959;
Everson and Cole, 1966). Although this 'immunological surveillance' of abnormal cells is difficult 3 . to demonstrate positively, the presence of such a $\delta$ control system is clearly shown by the increased potentiality to neoplastic activity taking place 0 after the administration of immunosuppressive drugs.

In 1906 Coley was able to show that a 'fluid' prepared from a haemolytic streptococcus and $\sigma$ Bacterium prodigiosum (Serratia marcescens), $N$ when repeatedly injected into patients with bone $\mathrm{W}^{-}$ sarcoma, was able to delay the further develop- -0 ment of the tumour and, in fact, could bring about the disappearance of metastases. A study $\frac{\bar{D}}{D}$ of these cases by Nauts, Fowler, and Bogatko in $\stackrel{\oplus}{?}$ 1953 showed that there had been a remarkable 0 longevity of survival in some cases. The injection $\overline{0}$ of dead Corynebacterium parvum has been shown $\vec{\AA}$ to reduce the growth of tumour in experimental $\frac{}{8}$ animals (Halpern, Biozzi, Stiffel, and Mouton, $\frac{\varrho}{0}$ 
1966). In man, many thoracic surgeons believe that the development of an empyema after a pneumonectomy for lung cancer, with the prolonged drainage of the infected hemithorax, appears to prolong the survival rate. As most cases are infected by Staphylococcus aureus, staphylococcal toxins may be responsible for the maintenance of a high level of non-specific immunity leading to increased lymphocyte and macrophage activity. Recent surveys (Sensenig, Rossi, and Ehrenhaft, 1963; Takita, 1970) show that where empyema complicated pneumonectomy the fiveyear survival rate was around $50 \%$ compared to the usual $20-25 \%$. A survey of the cases in our own unit did not support this view but, as most of them were of a period of 20-25 years ago, the management of this complication was less sophisticated than today.

Although there may be many bacterial agents that can produce an immunostimulant effect, the use of Bacille Calmette-Guérin (BCG) has been a favoured experimental procedure. Old and colleagues (Old, Clark, and Benacerraf, 1959; Old $e t$ al., 1961) demonstrated in animals that the inoculation of live BCG delayed the spread of homologous tumour grafts and transplanted tumours and also lowered the incidence of tumour development in susceptible strains of mice. Sjögren and Ankerst (1969) showed that the appearance of virus-induced tumours was delayed by BCG.

Non-bacterial agents that have been shown to have a markedly stimulant effect upon the reticulo-endothelial system are zymosan (a polysaccharide extract from yeast), oestrogens, and phytohaemagglutinin.

Consideration of the various agents at present available suggested that BCG provided the means of stimulating cell-mediated immunity that would be best tolerated by the human patient.

\section{CELL-MEDIATED IMMUNITY IN CARCINOMA OF THE LUNG IN MAN}

Carcinoma of the lung, as with carcinoma elsewhere, is associated not infrequently with a marked sinus hyperplasia in the draining lymph nodes (Black and Speer, 1958), and this is interpreted as marked activity of the sinusoidal macrophages and lymphocytes to deal with invasion by malignant cells. This feature has been accepted as an indication of a better prognosis for the longterm survival of the patient after surgery. Eventually the lymph-borne invasion becomes overwhelming, tumour cells become established in the structural tissues of the nodes, and their multiplication defeats the cellular defences. Increased macrophage and lymphocytic activity occurs at the edges of tumour masses (WyburnMason, 1969) as it does in the rejection phase of transplanted tissues (Green et al., 1967). This attempt by the body to remove abnormal tissues, while effective in non-growing transplants, fails once the tumour mass has attained any size, as the rate of malignant cell multiplication is greater than can be coped with by cellular activity at the periphery. Furthermore, the blood supply of most tumours is so reduced that the transportation of the macrophage-lymphocyte mechanisms into the tumour substance is limited.

Cell-mediated immunity is therefore likely to be effective only if the primary tumour is removed, together with any obviously involved nodes, and control obtained over isolated or small groups of cells that have metastasized distally. Metastases of any volume would suffer the same disadvantages as the primary tumour mass, and if such were present and unrecognized at the time of operation, they would be unlikely to be influenced by this adjuvant to therapy. Deaths from recurrence of a carcinoma in the first 12 to 18 months after the removal of all macroscopic tumour are nearly always due to the further development of these well-established distal metastases, and any improvement in the rate of survival would not be expected until after two years.

\section{METHOD OF ADMINISTRATION OF BCG}

The standard technique of BCG inoculation, using $0.1 \mathrm{ml}$ injected intradermally or by scarification, seemed inadequate to provide a stimulus over a period of months. This would require weekly or fortnightly visits to the hospital, which would not be acceptable to these usually rather elderly patients convalescing from a major thoracic operation and who may live many miles away. It was accordingly decided to give $0.5 \mathrm{ml}$ of BCG-Glaxo $(500,000$ organisms) subdermally in the deltoid region, which might result in an active lesion persisting for some four to six months. The injection of this dose subdermally produces a raised inflammatory mass, usually about $3 \mathrm{~cm}$ in diameter, which becomes fluctuant at the end of six weeks and in most cases resulted in a number of small discharging sinuses or an ulcer persisting for four to six months.

The induced BCG lesion produced little discomfort, and an adhesive dressing which the patient could renew daily dealt with the discharge. In only one case out of over 400 BCG inoculations of this type has a flagrant and spreading lesion developed, and this was controlled by the administration of INAH. In no case has a generalized systemic reaction occurred which could be attributed to the BCG. 


\section{ASSESSMENT OF RESULTS}

In view of the various manifestations of metastatic disease and the difficulty of detailed and frequent follow-up of a large number of patients, particularly in the older age group, it was considered that the establishment of length of survival was probably the only practical method of estimating whether BCG had had any influence on the development of metastases. It would be almost impossible to assess the true cause of death as most patients would die at home many months after their operation. Although some patients would succumb to a condition unconnected with the primary tumour, if the numbers of BCGtreated cases and controls were large enough, then this factor should tend to balance in the two groups. In view of the known variation in degree of malignancy of the various histological types of lung carcinoma, the groups would be divided into squamous, oat-cell, simplex, adenocarcinoma, alveolar-cell, and mixed types.

It is the policy of the surgeons of the Liverpool Centre not to undertake knowingly incomplete surgery of the tumour, except for severe symptoms, and any such cases were eliminated from the trial. The presence of ipsilateral malignant nodes did not preclude the resection of the tumour together with a radical dissection of these nodes.

Routine follow-up of these patients was made in the out-patient department but the final date of death was obtained from the Liverpool Cancer Control Organization to which all cases of cancer in the region are reported and who undertake a continuous survey by letter to the family practitioner. Necropsies were few.

In an attempt to estimate whether the effect of BCG could be quantitatively studied, lymphocytes were taken from a group of 50 patients. These were activated by phytohaemagglutinin (PHA) and the figures obtained after titration with radioactive thymidine were compared in the BCGtreated and control groups. Samples were taken preoperatively and postoperatively at 10 days, three months, six months, and one year. The results of this investigation are in preparation.

FIRST TRIAL This was to establish the safety of the use of BCG as an adjuvant to the surgery of carcinoma of the lung. In order to reduce the technical variables, the resection cases of one surgeon alone were studied.

Sixty consecutive surviving patients operated upon between October 1970 and December 1971 received BCG postoperatively and their length of life was compared with similar consecutive series of 60 patients operated upon between March 1969 and September 1970 and not receving BCG. The results given below are an interim report on this trial.

SECOND TRIAL This is a randomized trial involv- $\overrightarrow{0}$ ing five surgeons of the Liverpool Cardio-Thoracic $\overrightarrow{\vec{\omega}}$ Surgical Centre. Starting in December 1971, all cases of lung resection for carcinoma, which ful- $\vec{F}$ filled the above criteria, were randomized and half $\vec{x}$ were given BCG, the other half remaining as a 0 control group. Five hundred cases are now documented and available for study, but it is as yet too of early to assess these results on a survival basis.

RESULTS IN FIRST TRIAL In view of the length of $z$ time necessary to cover the survival periods, the following is an interim report on the first trial, which was not randomized but reflected a standardized pattern in surgical treatment.

The basic data on the control and BCG groups $\vec{\oplus}$ are shown in Table $I$. The surgical indications, $\perp$ technique, and management had been standardized over many years and were not knowingly different in any detail in either group. Except for 10 specimens which were reported elsewhere, all resected material in both groups was submitted to the same pathologist who reported on the histological type of tumour and the lymph node involvement. All histological reports referred to the removed tumour and not to bronchoscopic biopsy specimens, in which we have found a $7 \%$ typing error when compared to the removed specimen (Whitwell, 1961).

No patient in either group received definitive treatment with radiotherapy or chemotherapy,

T A B L E I

BASIC DATA OF THE NON-BCG AND BCG GROUPS

\begin{tabular}{|c|c|c|c|c|}
\hline \multirow[b]{2}{*}{$\begin{array}{l}\text { Total no. of cases } \\
\text { Postoperative deaths }\end{array}$} & \multicolumn{2}{|c|}{$\begin{array}{l}\text { Non-BCG } \\
\text { Group }\end{array}$} & \multicolumn{2}{|c|}{$\begin{array}{l}\text { BCG Group } \\
\text { (1st Trial) }\end{array}$} \\
\hline & $\begin{array}{r}64 \\
4\end{array}$ & $7 \%$ & $\begin{array}{r}63 \\
3\end{array}$ & $5 \%$ \\
\hline $\begin{array}{l}\text { No. of survivors } \\
\text { Male } \\
\text { Female }\end{array}$ & $\begin{array}{r}60 \\
54 \\
6\end{array}$ & $\begin{array}{l}90 \% \\
10 \%\end{array}$ & $\begin{array}{r}60 \\
53 \\
7\end{array}$ & $\begin{array}{l}88 \% \\
12 \%\end{array}$ \\
\hline $\begin{array}{l}\text { Operation } \\
\text { Pneumonectomy } \\
\text { Lobectomy }\end{array}$ & $\begin{array}{l}32 \\
28\end{array}$ & $\begin{array}{l}53 \% \\
47 \%\end{array}$ & $\begin{array}{l}32 \\
28\end{array}$ & $\begin{array}{l}53 \% \\
47 \%\end{array}$ \\
\hline $\begin{array}{l}\text { Histology } \\
\text { Squamous } \\
\text { Oat-cell } \\
\text { Adeno- } \\
\text { Simplex } \\
\text { Mixed } \\
\text { Clear-cell } \\
\text { Adenomatosis }\end{array}$ & $\left.\begin{array}{r}30 \\
9 \\
13 \\
3 \\
3 \\
1 \\
1\end{array}\right\}$ & $\begin{array}{l}50 \% \\
15 \% \\
22 \% \\
5 \% \\
5 \% \\
3 \%\end{array}$ & $\begin{array}{r}35 \\
8 \\
12 \\
1 \\
4\end{array}$ & $\begin{array}{r}58 \% \\
13 \% \\
20 \% \\
2 \% \\
6 \%\end{array}$ \\
\hline
\end{tabular}
.

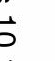


except to relieve symptoms of metastases in the late stages where indicated.

The survival rate at one year is shown in Table II, which gives an expected similar figure in both groups, as the cause of death during this period would be, in most cases, due to well-established latent metastases present at the time of operation.

T A B L E I I

SURVIVAL AT ONE YEAR

\begin{tabular}{|c|c|c|c|c|}
\hline \multirow{2}{*}{\begin{tabular}{l}
\multicolumn{1}{c}{ Histology } \\
Squamous \\
Oat-cell \\
Adeno- \\
Simplex \\
Mixed \\
Clear-cell \\
Adenomatosis
\end{tabular}} & \multicolumn{2}{|c|}{ Control Group } & \multicolumn{2}{|c|}{ BCG Group } \\
\hline & $\begin{array}{c}21 / 30 \\
1 / 9 \\
8 / 13 \\
1 / 3 \\
1 / 3 \\
0 / 1 \\
1 / 1 \\
\end{array}$ & $\begin{array}{l}70 \% \\
11 \% \\
61 \% \\
33 \% \\
35 \% \\
= \\
\end{array}$ & $\begin{array}{c}23 / 35 \\
5 / 9 \\
5 / 12 \\
1 / 1 \\
0 / 4 \\
= \\
-\end{array}$ & $\begin{array}{r}66 \% \\
55 \% \\
42 \% \\
100 \% \\
0 \% \\
= \\
\end{array}$ \\
\hline Total & $33 / 60$ & $55 \%$ & $36 / 60$ & $57 \%$ \\
\hline
\end{tabular}

The survival rate at two years is shown in Table III. Here the survival rate of all histological types has risen from $38 \%$ in the control group to $52 \%$ in the BCG group. With squamous carcinoma the survival rate has risen from $50 \%$ in the control group to $62 \%$ in the BCG group $\left(\chi^{2}=1.09\right)$, and in the positive node cases the survival has risen from $33 \%$ to $53 \%\left(\chi^{2}=0.54\right.$ with Yates's correction). In the oat-cell carcinomas, survival has risen from $11 \%$ in the control to $50 \%$ in the BCG groups, but the numbers are small $\left(\chi^{2}=1.83\right.$ with Yates's correction). Very little change is noted in the other histological groups.

The results so far indicate that, although there is a trend towards improved survival at two years-in patients who have received BCG following lung resection, no figures are as yet statistically significant, and we await the evaluation of these cases at three, four, and five years. It is only when the results of the fully randomized trial (trial 2) are available that a final answer can be given as to whether this strain of BCG administered by the described technique has any effect upon the proliferation of cancer cells.

Our grateful thanks are due to Miss Katharine Edwards, B.Sc. and Miss Barbara White for their help in organizing this trial; to Dr. J. T. A. Lloyd, of the Royal Alexandra Hospital, Rhyl, for 10 of the pathological reports and to the Liverpool University Cancer Research Committee for financial assistance.

\section{REFERENCES}

Black, M. M. and Speer, F. D. (1958). Sinus histiocytosis of lymph nodes in cancer. Surgery, Gynaecology and Obstetrics, 106, 163.

Coley, W. B. (1906). Late results of the treatment of inoperable sarcoma by the mixed toxins erysipelas and $B$. prodigiosus. American Journal of the Medical Sciences, 131, 375.

Everson, T. C. and Cole, W. H. (1966). Spontaneous Regression of Cancer. Saunders, Philadelphia.

Gordon-Taylor, G. (1959). The incomputable factor in cancer prognosis. British Medical Journal, 1, 455.

Green, H. N., Anthony, H. M.. Baldwin, R. W., and Westrop, J. W. (1967). An Immunological Approach to Cancer. Butterworth, London.

Halpern, B. N., Biozzi, G., Stiffel, C., and Mouton, D. (1966). Inhibition of tumour growth by the administration of killed Cornebacterium parvum. Nature, 212, 853.

Nauts, H. C., Fowler, G. A., and Bogatko, F. H. (1953). A review of the influence of bacterial infection and of bacterial products (Coley's toxins) on malignant tumors in man. Acta Medica Scandinavica, 145, Supplement, p. 276.

Old, L. J., Benacerraf, B., Clarke, D. A., Carswell, E. A., and Stockert, E. (1961). The role of the reticuloendothelial system in the host reaction to neoplasia. Cancer Research, 21, 1281.

, Clarke, D. A., and Benacerraf, B. (1959). Effect of bacillus Calmette-Guérin injection on transplanted tumours in the mouse. Nature, 184, 291.

T A B L E I I I

TWO-YEAR SURVIVAL

\begin{tabular}{|c|c|c|c|c|c|c|c|c|c|c|c|c|c|c|c|c|}
\hline \multirow[b]{3}{*}{ Type } & \multicolumn{8}{|c|}{ Non-BCG } & \multicolumn{8}{|c|}{ BCG } \\
\hline & \multirow{2}{*}{\multicolumn{2}{|c|}{ No. $\%$}} & \multicolumn{3}{|c|}{ Alive } & \multicolumn{3}{|c|}{ Dead } & \multirow[b]{2}{*}{ No. } & \multirow[b]{2}{*}{$\%$} & \multicolumn{3}{|c|}{ Alive } & \multicolumn{3}{|c|}{ Dead } \\
\hline & & & No. $\%$ & $\mathbf{N}+$ & N- & No. & $\mathrm{N}+$ & N- & & & No. $\%$ & $\mathrm{~N}+$ & N- & No. & $\mathbf{N}+$ & N- \\
\hline $\begin{array}{l}\text { Squamous } \\
\text { Oat-cell } \\
\text { Adeno- } \\
\text { Simplex } \\
\text { Mixed } \\
\text { Clear-cell } \\
\text { Adenomatosis }\end{array}$ & $\begin{array}{r}30 \\
9 \\
13 \\
3 \\
3 \\
1 \\
1\end{array}$ & $\begin{array}{r}50 \\
15 \\
22 \\
5 \\
5 \\
3\end{array}$ & \begin{tabular}{rr}
15 & 50 \\
1 & 11 \\
4 & 31 \\
1 & 33 \\
1 & 33 \\
\cline { 1 - 2 } & \multicolumn{1}{c}{100}
\end{tabular} & $\begin{array}{l}5 \\
1 \\
1 \\
= \\
=\end{array}$ & $\begin{array}{l}\frac{10}{3} \\
\frac{1}{1}\end{array}$ & $\begin{array}{r}15 \\
8 \\
9 \\
2 \\
2 \\
1 \\
-\end{array}$ & $\begin{array}{r}10 \\
6 \\
5 \\
1 \\
1 \\
-\end{array}$ & $\begin{array}{l}5 \\
2 \\
4 \\
1 \\
1 \\
1 \\
-\end{array}$ & $\begin{array}{r}35 \\
8 \\
12 \\
1 \\
4 \\
- \\
-\end{array}$ & $\begin{array}{r}58 \\
13 \\
20 \\
2 \\
6 \\
-\end{array}$ & $\begin{array}{rr}22 & 62 \\
4 & 50 \\
4 & 33 \\
1 & 100 \\
- & = \\
& =\end{array}$ & $\begin{array}{l}8 \\
2 \\
= \\
= \\
=\end{array}$ & $\begin{array}{r}14 \\
2 \\
4 \\
1 \\
- \\
-\end{array}$ & $\begin{array}{r}13 \\
4 \\
8 \\
-4 \\
-\end{array}$ & $\begin{array}{l}7 \\
3 \\
5 \\
3 \\
-\end{array}$ & $\begin{array}{r}6 \\
1 \\
3 \\
1 \\
-\end{array}$ \\
\hline Total & 60 & - & $23 \quad 38$ & 7 & 16 & 37 & 23 & 14 & 60 & - & 3152 & 10 & 21 & 29 & 18 & 11 \\
\hline
\end{tabular}

$\mathrm{N}+=$ positive nodes; $\mathrm{N}-=$ negative nodes. 
Sensenig, D. M., Rossi, N. P., and Ehrenhaft, J. L. (1963). Results of the surgical treatment of bronchogenic carcinoma. Surgery, Gynaecology and Obstetrics, 116, 279.

Sjögren, H. O. and Ankerst, J. (1969). Effect of bacille Calmette-Guérin and allogeneic tumour cells on adenovirus type 12 tumorigenesis in mice. Nature, 221, 863.

Southam, C. M. (1965). Evidence of immunological reactions to autochthonous cancer in man. European Journal of Cancer, 1, 173.

Takita, H. (1970). Effect of post-operative empyema on survival of patients with bronchogenic car- cinoma. Journal of Thoracic and Cardiovascular Surgery, 59, 642.

Whitwell, F. (1961). The histopathology of lung cancer in Liverpool. A study of bronchial biopsy histology. British Journal of Cancer, 15, 429.

Wyburn-Mason, R. (1969). Immunity to cancer. \& British Medical Journal, 2, 765.

Requests for reprints to: F. Ronald Edwards, FRCS, Liverpool Cardio-Thoracic Surgical Centre, Broadgreen Hospital, Thomas Drive, Liverpool L14 3LB. 